\title{
When psychological ownership nurtures satisfaction: a tripartite attitude theory and psychological ownership theory perspective
}

Muhammad Bello Jakada

Department of Actuarial Science, Federal University Dutse, Dutse, Nigeria Najib Sabo Kurawa

Department of Business Administration, Federal University Dutse, Dutse, Nigeria Aliyu Rabi'u

Department of Actuarial Science, Federal University Dutse, Dutse, Nigeria Armaya'u Alhaji Sani

Department of Accounting, Federal University Dutse, Dutse, Nigeria

Ahmed Ibrahim Mohammed

Department of Banking and Finance, Federal University Dutse, Dutse, Nigeria, and Abdurrahman Umar

Department of Business Administration, Federal University Dutse, Dutse, Nigeria

\begin{abstract}
Purpose - Drawing from tripartite theory of attitude, this study examined whether interaction effect of psychological ownership (cognitive component) changes the nature of the relationship between job satisfaction (affect component) and job performance (behavioral component) toward a higher or weaker relationship. Furthermore, the study draws from psychological ownership theory to find support whether job satisfaction is nurtured by the feeling of psychological ownership.

Design/methodology/approach - Longitudinal data from 211 academic and non-academic employees was randomly collected and partial least square-structural equation model (PLS-SEM) was used for data analysis through SmartPLS version 3.3.2.

Findings - The study found a positive interaction effect of psychological ownership on the relationship between job satisfaction and job performance. Furthermore, the study found that feeling of psychological ownership nurtures employees' satisfaction with their job.

Practical implications - The findings of the study explicate to human resource managers and practitioners the mechanism through which job satisfaction affects job performance and how feelings of psychological ownership nurtures employees' satisfaction with their job.

Originality/value - The study provides new insight into the relationship between job satisfaction and job performance by drawing on the tripartite theory of attitude perspective, and concluded that job performance as overall employee attitude toward the organization is predicted by the interaction and interplay of job satisfaction, psychological ownership and job performance as components of attitude. To the authors' best knowledge, none of the previous literatures on job satisfaction-job performance relationship draws its
\end{abstract}

(C) Muhammad Bello Jakada, Najib Sabo Kurawa, Aliyu Rabi'u, Armaya’u Alhaji Sani, Ahmed Ibrahim Mohammed and Abdurrahman Umar. Published in Rajagiri Management Journal. Published by Emerald Publishing Limited. This article is published under the Creative Commons Attribution (CC BY 4.0) licence. Anyone may reproduce, distribute, translate and create derivative works of this article (for both commercial and non-commercial purposes), subject to full attribution to the original publication and authors. The full terms of this licence may be seen at http://creativecommons.org/licences/by/4.0/ legalcode

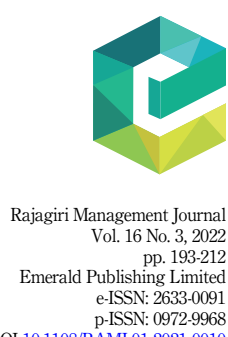

Received 31 January 2021 Revised 9 April 2021 Accepted 30 April 2021

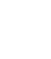


RAMJ

16,3 conclusions from the perspective of tripartite theory of attitude. Furthermore, the study found empirical evidences that psychological ownership nurtures employees' job satisfaction.

Keywords Affect, Attitude, Behavior, Cognitive, Interaction effect, Job performance, Job satisfaction,

Psychological ownership

Paper type Research paper

\section{4}

\section{Introduction}

Job satisfaction (JS) and job performance (JP) are perhaps the two most central and enduring sets of constructs in individual-level organizational research (Harrison et al., 2006). JS is a vital factor in human resource practices which leads to organizational efficiency (Cummings and Worley, 2014). Armstrong and Taylor (2014) defined JS as the feelings people have about their job: positive and favorable attitudes toward the job indicate JS. Therefore, highly satisfied work force is an ingredient for achieving higher JP for higher organizational performance (Ölçer, 2015). Culibrk et al. (2018) opined that satisfied employees are imperative for contemporary organizations and is one of the key factors that distinguish successful organizations from the alternative. Therefore, creating a satisfied employee is essential for the betterment of the organization. Human resources are very vital and most valuable resources without which the organizations could not be able to achieve higher performance (Nielsen and Montemari, 2012) since organizational performance is a shared outcome from each individual's performance (Fontannaz and Oosthuizen, 2007). JS is a key element of work motivation and one of the fundamental determinants of employees' behavior in organization (Culibrk et al., 2018). These literatures underscore the need for organizations to ensure JS of their employees.

Existing literatures documented the importance of JS in leading to positive behavioral outcomes which in turn have effect on organizational performance. For example, JS affects organizational commitment (Valaei and Rezaei, 2016; Srivastava, 2013), employee engagement (Garg et al., 2017; Susan, 2012), loyalty (Matzler and Renzl, 2006), entrepreneurial behavior (Mustafa et al., 2016), organizational performance (Bakotić, 2016) and JP (Tella and Ibinaiye, 2019; Theresia et al., 2018). However, whether JS leads to JP is still debated.

Studies on the relationship between JS and JP continually produced inconsistent findings (Yang and Hwang, 2014): thus there is no consensus regarding the various models that explain the relationship (Judge et al., 2001). Various reasons were perceived to have accounted for the inconsistent findings. For example, JS and its facets vary across context (country and organization) and change over time (Westover and Taylor, 2010) such that what satisfied an individual now may not be the same in the future (Locke, 1970). Satisfaction is subjective that varies across individuals, organizations and country. For example, while the study by Garg et al. (2017) found that managers of private banks in India are more satisfied with intrinsic JS, Markovits et al. (2014) reported that extrinsic JS is the priority among employees in Greece (promotion). Another reason is ascribed to differences in conceptualization of JS and JP, e.g. whether performance is defined in terms of task or contextual performance (Organ, 1988). Therefore, JS-JP relationship should be studied cross-culturally and over time (Valaei and Jiroudi, 2016). Specifically, the failed relationships suggested that JS-JP relationship is likely contingent upon individual and/or situational moderators (Schwab and Cummings, 1970): thus, Judge et al. (2001) suggested the exploration of moderator in order to help explain the inconsistent and weak relationship.

Few scholarly attempts were made to examine the relationship via moderator. Valaei and Jiroudi (2016), Yang and Hwang (2014), Ferris et al. (2009), Foote and Li-Ping Tang (2008), Norris and Niebuhr (1984) have reported a positive interaction of demographic variables, personality trait, job-limiting pain and political skill, team commitment and organizational 
tenure. However, these studies failed to address the relationship through the interplay of tripartite attitude. Locke (1970) opined that it is misleading to believe that satisfaction affects performance because individual's emotion/affect does not control his/her behavioral outcome. Attitude is a component of cognition, affect and behavior whose interplay influence attitude and attitude change (Katz and Stotland, 1959; Millar and Tesser, 1989; Rosenberg and Hovland, 1960; Zanna and Rempel, 1988). Therefore, there is a need for empirical examination of JS-JP relationship as an interplay of three components of attitude. This study addresses this literature gap. The study conceptualizes model of relationship between affect, cognitive and behavioral components which in turn manifested the overall employee attitude toward the organization.

JS is viewed from different perspectives in relation to attitudes. Some scholars perceived JS from affective component of attitude and present it as whole, general, or global feelings about the job (Spector, 1997; Moorman, 1993; Kalleberg, 1977). For example, JS is defined as an affective subjective construct that represents an overall emotional feeling individuals have about their job as a whole (Kalleberg, 1977; Moorman, 1993). Similarly, JS was conceived as a global feeling about the job (Spector, 1997). However, JS is generally construed in affective terms (Brief and Weiss, 2002). It is suggested that affective JS as an overall feeling about a job as a whole, directly reflects and thus comprises the aggregate of cognitive JS facets (Thompson and Phua, 2012). Therefore, this study perceived JS as an affect component of attitude.

$\mathrm{JP}$ is defined as the whole attitudes and actions that are judged as vital for accomplishing the goals of the organization (Campbell et al., 1990). It is employee behaviors that are consistent with role expectations and that contribute to organizational effectiveness (Judge and Kammeyer-Mueller, 2012). Therefore, JS is the overt actions and responses to the attitude object (Fabrigar et al., 2005). This study perceived JP as behavioral component of attitude. However, JP is a multifaceted construct and differences in conceptualization and operationalization of JP in terms of task or contextual performance is attributed to persistent inconsistent conclusions on the nature of JS-JP relationship. Koopmans et al. (2013), Judge and Kammeyer-Mueller (2012) perceived JP as an outcome of task performance, contextual performance and counterproductive work behaviors. On the other hand, while Johnson (2001), Borman and Motowidlo (1997) categorized JP into task and contextual performance, MacKenzie et al. (1998) categorized JP into in-role and extra-role, and Williams and Anderson (1991) classified JP into in-role behavior and organizational citizenship behavior. However, this study adopted the model of Koopmans et al. (2013) and Judge and Kammeyer-Mueller (2012). The present study perceived overall JP as an antecedent of task performance, contextual performance and counterproductive work behaviors, thus, avoided the problem of conceptualizing JP to certain facets.

Task performance is the traditional in-role performance, which is the rudimentary constituent of performance appraisal that directly measures task outcomes and relates directly to work effectiveness that contributes to the organization's technical core (Yang and Hwang, 2014). Contextual performance consists of volunteering to undertake activities that are not formally part of the job, and aiding and cooperating with others in the organization to accomplish tasks (Borman and Motowidlo, 1997). Counterproductive work behaviors are responses to dissatisfaction that often go against organizational interests or norms (Judge and Kammeyer-Mueller, 2012) and threatens the well-being of the organization, its members or both (Robinson and Bennett, 1995) e.g. absenteeism, being late for work, theft, substance abuse etc.

Specifically, this study intends to extend the present literature in four folds. First, the study draws from the tripartite theory of attitudes perspective and examines the interaction effect of psychological ownership (PO) on JS-JP relationship based on the constructionist perspective of attitude. Second, the study draws from PO theory to find support whether JS is 
RAMJ

16,3

nurtured from feeling of PO such that when employees' sense of PO is high their satisfaction with the job is fostered. Third, the present study reflects all the three attitude components into manifested constructs. Therefore, the model is rather overt that can be understood easily, aids decision-making by managers and practitioners, and influences management practices and programs. Fourth, the study contributes to methodology.

\section{6}

\section{Literature review and hypothesis development}

Job satisfaction and job performance

Relationship between JS and JP is one of the most studied relationships in human resource management field. For example, while meta-analysis study by Iaffaldano and Muchinsky (1985) identified 74 studies on JS and JP and reported a correlated correlation of 0.17 , Jugde et al. (2001) sampled 312 studies out of 54,417 and reported a correlated correlation of 0.30 . However, one obvious issue from the extant literatures is continuous inconsistent conclusions by the studies on JS-JP relationship. Studies conducted as recent as in 2018 and 2019 reported different conclusions. For example, while a study by Hazriyanto and Silitonga (2019), Mira et al. (2019) reported a positive and significant relationship between JS and JP, studies by Eliyana et al. (2018), Agustiningsih et al. (2016) reported non-significant relationship between JS and JP. Similarly, Ezeamama (2019) concluded that JS does not lead to employee productivity. Christen et al. (2006) argued it is difficult to obtain support on the view that JS has a significant effect on JP; thus, one of the least successfully resolved relationships in literature (Hochwarter et al., 1999). Zeffane et al. (2008) opined that even though several researchers have attempted to address the relationship between JS and JP, their study conclusions could not agree on the strength or direction of the relationship. Therefore, understanding the mechanism through which the relationship between these two important constructs can be enhanced is of utmost importance to knowledge and practitioners.

However, we would like to emphasize that examining the direct effect of JS on JP is not among the primary aims of this study because literature has said enough about it. But there is no unanimity on the particular direction and strength of the relationship. Direct effect hypothesis can best be ignored and declared as a well-known argument when there is consensus on the relationship from the literature viewpoint (Anderson et al., 2014) which is not the case between JS and JP. In addition, Judge et al. (2001) emphasized that the merit of JS$\mathrm{JP}$ model is dependent on the magnitude of their bivariate relationship such that a very low magnitude means no point to examine the model. Consequently, the study hypothesized that:

H1. JS has significant effect on JP.

\section{Moderating effect of psychological ownership}

$\mathrm{PO}$ is the psychologically experienced phenomenon where an employee develops possessive feelings for the target (Van Dyne and Pierce, 2004). The targets include personal or group attachment, facilities in the work place and personal output in an organization (Avey et al., 2009). These definitions implied that $P O$ is a cognitive sense of possessive ownership toward a particular target which reflects a bonded relationship between an individual and the target. Therefore, $\mathrm{PO}$ as cognitive component of attitude can be refers as beliefs that one holds about the attitude object (Robbins and Judge, 2013; Fabrigar et al., 2005). This study perceived PO as a cognitive component of attitude. Employees feel psychologically entwined with their organizations, and these feelings are accompanied by the feeling of responsibility and a sense of commitment for the effective functioning and success of the organization (Pierce et al., 2001).

PO fulfills employees' basic needs of efficacy, self-identity and having a place (Pierce $e$ t al., 2001) which provides an avenue in which satisfaction can be nurtured (Kozlowski and Klein, 
2000). Van Dyne and Pierce (2004) affirmed that PO for organization has implication for employees' satisfaction. In a similar argument, PO is an affective judgment which comprises both affective and cognitive information (Van Dyne and Pierce, 2004). Hence, having sense of PO meant that employees are more satisfied with their job (Zhang et al., 2020). Employees who developed a sense of $\mathrm{PO}$ perceived themselves as owners and the possessions become part of their self-concept (Tian and Belk, 2005). Therefore, $\mathrm{PO}$ is vital for the development of positive organizational behaviors among employees (Hernandez, 2012), hence, a powerful employee motivator (Liu et al., 2012). Therefore, this study draws from the PO theory and perceived that the pleasure that employees drive from the feeling of $\mathrm{PO}$ fosters their satisfaction with their job. In other words, this study argued that employees' JS as their affective component is fostered from their cognitive information (feelings of PO).

Tripartite theory of attitude was also found suitable to further underpin this study. Locke's assertion that emotion/affect does not control individual's behavioral outcome is in congruent with the view of proponents of tripartite attitude theory. The proponents of tripartite theory of attitude argued that consistent evaluation of affect, cognition and behavior determines attitude (Katz and Stotland, 1959; Rosenberg and Hovland, 1960). Therefore, attitude is developed from the interplay of cognitive, affective and behavioral information (Zanna and Rempel, 1988). Previous studies have utilized and found the usefulness of tripartite attitude theory in understanding and predicting both individual and group attitude (Lu et al., 2017; Jackson et al., 1996; Haddock et al., 1994). For example, Lu et al. (2017) showed the importance of tripartite attitude theory in understanding employee attitude and suggested that the interplay of cognition (PO), behavior (territoriality) and affect (work closeness) contribute to the prediction of employee attitude toward turnover intention. Similarly, Jackson et al. (1996) revealed that, group attitude is derived not only from stereotypes and values (cognitions) but also from affects and behavior associated with the group. The theory could help our understanding on whether the interplay of affect, cognition and behavior explains better the disputed effect of JS on JP. Therefore, the study hypothesized that:

H2. The relationship between JS and JP is stronger when employees' PO is higher and weaker when PO is low.

\section{Method}

Sample

The samples of this study were university employees from Federal University Dutse (FUD), Nigeria. The data were collected over the period of 11 months to attenuate common method bias potential and enhance the causality/predictability among the variables (Podsakoff et al., 2003). In phase one, employees provided information on demography and JS. Six months later, they provided information on their performance. Five months after the phase two, they provided information on PO. The questionnaires were either personally distributed or mailed to the randomly selected 285 employees. In each phase, the questionnaires were sent to the same employees whose details were obtained from the registry department. Only the data from the participants who have not changed their job were used for data analysis. All in all, 211 valid responses were used for data analysis. $71 \%$ of the respondents were male, $29 \%$ were female, majority of the respondents $(60 \%)$ were between the age of $26-35$, and $26 \%$ were 36 years and above. Similarly, $75 \%$ of the respondents have first degree and above, while $72 \%$ of the respondents have working experience of 'between 0 and $15 \mathrm{yrs}$.

Working conditions in Nigerian Universities are dissatisfying. JS factors are generally lacking in Nigerian Universities (Olofinkua, 2020; Idiegbeyan-Ose et al., 2019; Opeke et al., 2019). However, in spite of the poor working conditions, FUD is ranked as the best university 
RAMJ

16,3

in Nigeria (Scimago Institution Ranking, 2020). Literatures asserted that employees who have a sense of PO for an organization presumed personal risks, obligations and accountability toward their actions and decisions which lead to organizational success (Md-Sidin et al., 2010). Hence, this study argued that feeling of PO fostered JS of FUD employees toward their action (outstanding performance). Consequently, the attitude of FUD employees could help understand whether JS is nurtured from feeling of PO toward higher JP.

\section{Measurement of research variables}

All the measurement scales of this study were adapted from previous studies and measured based on a five-point Likert scale from 1 (strongly disagree) to 5 (strongly agree).

\section{Job satisfaction}

A generic JS scale (GJSS) developed by Macdonald and Maclyntyre (1997) was used to measure JS. GJSS was developed to measure overall JS using employees from various occupations which allows for its applicability across different sectors (Bailey et al., 2016). The instrument was used by many researchers (Bailey et al., 2016; Mohamad, 2012; Marcinkus et al., 2007) and an internal consistency of 0.88 was reported by Marcinkus et al. (2007). The instrument has 10 items and was adapted from the work of McDonald and Maclyntyre (1997). Example item is "I receive recognition for job well done."

\section{Psychological ownership}

PO was measured using an instrument developed by Van Dyne and Pierce (2004). The instrument has received wide recognition and was used by many studies (Dawkins et al., 2015). An internal consistency of 0.87 was reported by Li et al. (2015). The instrument has 7 items and was adapted from the work of Van Dyne and Pierce (2004). Example item is "I sense that this is MY University."

\section{Job performance}

Koopmans et al.'s (2014) improved version of individual work performance questionnaire (IWPQ) was used to measure JP. This study utilizes this measurement to literally avoid conceptualization issue of JP. IWPQ has covered all the three critical dimensions of individual work performance (task performance, contextual performance and counterproductive work behavior) and thus can be used for all types of occupations (Daderman et al., 2019; Hrdzic, 2016). The questionnaire has 18 items, and Daderman et al. (2019) reported an internal consistency of above 0.7. The instrument was adapted from the work of Koopmans et al. (2014). Example items are "I managed to plan my work so that it was done on time," "I took on extra responsibilities," "I complained about unimportant matters at work."

\section{Data analysis}

This study utilizes partial least square-structural equation model (PLS-SEM) for data analysis. PLS gives more accurate estimates of moderator effects by accounting for the error that lessens the estimated relationships and improves the validation of theories (Henseler and Fassott, 2010). More importantly, PLS-SEM is a causal-prediction approach that emphasizes estimating statistical models, whose structures are designed to provide causal explanations (Sarstedt et al., 2017). Therefore, PLS-SEM overcomes the ostensible dichotomy between explanation emphasized in academic research and prediction, which is the basis for developing managerial implications (Hair et al., 2019).

Apart from ex ante method adopted by this study to minimize potentials of common method bias (CMB), we still utilized ex-post method as recommended by Fuller et al. (2016). 
$\mathrm{CMB}$ was assessed through full collinearity test based on the threshold of variance inflation factor (VIF) of $\leq 3.3$ suggested by (Kock, 2015). To conduct a collinearity test for possible CMB on PLS-SEM model, the variables are all connected to one variable at a time and the same process is applied on each variable in the model (Gaskin, 2017). The model of this study does not show any possible CMB (see Table 1).

\section{Results}

\section{Measurement model}

The measurement model was assessed via loadings, composite reliability (CR), average variance extracted (AVE), rho "A" and HTMT as recommended by Hair et al. (2019).

The loadings are adequate (Table 2) since that all the items exceeded the minimally recommended value of 0.5 (Hooper et al., 2008; Hulland, 1999). CR determines the internal consistency of the construct measuring items. CR values for JS, PO and JP are within the recommended region by Hair et al. (2019) of above 0.7. CR is more a precise measure of reliability compared with Cronbach's alpha because the later does not weight items (Hair et al., 2019). The AVE was used to assess convergent validity of the constructs, and the values were all above the threshold of 0.5 suggested by Hair et al. (2019).

Table 3 presents the Heterotrait-monotrait (HTMT) discriminant validity results. The HTMT criterion is that when the value of HTMT is greater than 0.85 then there is lack of discriminant validity (Henseler et al., 2015; Kline, 2011). All the HTMT values for both constructs were less than the recommended threshold hence, displayed discriminant validity (see Figure 1).

\begin{tabular}{lccc}
\hline Latent variable & JS & JP & PO \\
\hline JS & & 1.82 & 1.81 \\
JP & 1.20 & & 1.20 \\
PO & 1.72 & 1.625 &
\end{tabular}

Source(s): PLS-SEM
Psychological ownership

\begin{tabular}{|c|c|c|c|c|c|}
\hline Construct & Items & Loadings & AVE & $\mathrm{CR}$ & rho A \\
\hline \multirow[t]{3}{*}{ Job Performance } & Task Performance & 0.869 & \multirow[t]{3}{*}{0.605} & \multirow[t]{3}{*}{0.817} & \multirow[t]{3}{*}{0.817} \\
\hline & Contextual Performance & 0.857 & & & \\
\hline & Counterproductive Work Behavior & 0.57 & & & \\
\hline \multirow[t]{8}{*}{ Job Satisfaction } & JS1 & 0.666 & \multirow[t]{8}{*}{0.522} & \multirow[t]{8}{*}{0.896} & \multirow[t]{8}{*}{0.905} \\
\hline & JS2 & 0.716 & & & \\
\hline & JS3 & 0.756 & & & \\
\hline & JS4 & 0.581 & & & \\
\hline & JS6 & 0.667 & & & \\
\hline & JS8 & 0.721 & & & \\
\hline & JS9 & 0.843 & & & \\
\hline & JS10 & 0.794 & & & \\
\hline \multirow[t]{5}{*}{ Psychological Ownership } & PO1 & 0.865 & \multirow[t]{5}{*}{0.559} & \multirow[t]{5}{*}{0.863} & \multirow[t]{5}{*}{0.852} \\
\hline & $\mathrm{PO} 2$ & 0.691 & & & \\
\hline & PO3 & 0.705 & & & \\
\hline & PO6 & 0.781 & & & \\
\hline & PO7 & 0.682 & & & \\
\hline
\end{tabular}

Note(s): Items deleted due to poor loadings: JS5, JS7, PO4 and PO5 Source(s): PLS-SEM

Table 2. Convergent validity and reliability 
RAMJ 16,3

200
The model fit was assessed via standardized root-mean residuals (SRMR) and normed-fit index (NFI). SRMR determines the extent of the discrepancies between residuals of the sample covariance matrix and hypothesized covariance model (Hooper et al., 2008). This study obtained an estimated model value of 0.077 for SRMR which is within the threshold of $\leq 0.08$ recommended by Hu and Bentler (1999). NFI compares the $\chi^{2}$ value of the model to the $\chi^{2}$ of the null model (Hooper et al., 2008). An estimated model value of 0.96 is recorded by this study which is within the threshold of $\geq 0.95$ recommended by Hu and Bentler (1999) (see Figure 2).

\section{Structural model and test of hypotheses}

The structural model of this study is a reflective model, thus was assessed via coefficient of determination $\left(R^{2}\right)$, blindfolding-based cross-validated redundancy (predictive relevance, $Q^{2}$ ), statistical significance and relevance of path coefficient as suggested by Hair et al. (2019).

$Q^{2}$ is a blindfolding procedure which determines the predictive relevance of the PLS-path model based on threshold of $>0,>0.25$ and $>0.50$ for small, medium and large (Hair et al., 2019). $R^{2}$ determines the explanatory power of the model based on variance explained by the endogenous constructs (Shmueli and Koppius, 2011). $R^{2}$ values of 0.75, 0.50 and 0.25 present large, moderate and weak explanatory power (Henseler et al., 2009). Therefore, based on the results in Table 5, hypothesis one is accepted (see Figure 4).

Product indicator approach was used for the analysis of the moderation effect as recommended by the Memon et al. (2019). Similarly, the reporting format focuses on the significance of the interaction effect significance ( $\phi$-value), effect size $\left(F^{2}\right), R^{2}$ and simple slope analysis as suggested by Memon et al. (2019).

Figure 5 shows the interaction effect of $\mathrm{PO}$ as a moderator on the relationship between JS and JP particularly at lower level of PO of $-1 \mathrm{SD}$ (represented by red line) and higher level of $\mathrm{PO}$ at $+1 \mathrm{SD}$ (represented by green line). The moderation effect is positive since all the three lines moved toward the direction of positive region to the right. The simple slope analysis

\begin{tabular}{lccc}
\hline Construct & JP & JS & PO \\
\hline JP & & & \\
JS & 0.561 & 0.408 & \\
PO & 0.677 & & \\
Source(s): PLS-SEM & & &
\end{tabular}

Table 3.

Heterotraitmonotrait (HTMT)

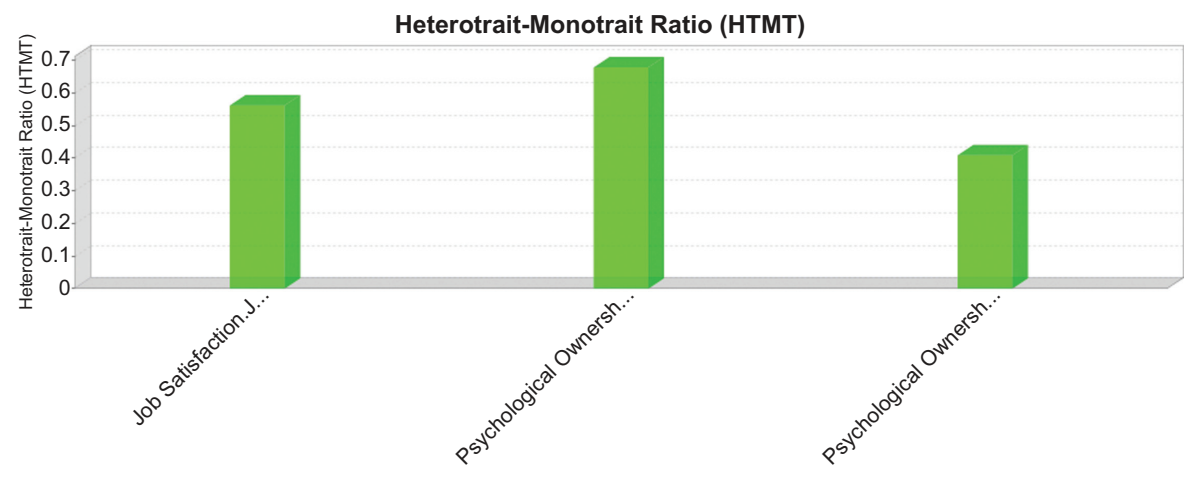

Source(s): PLS-SEM
Figure 1.

Discriminant validity 


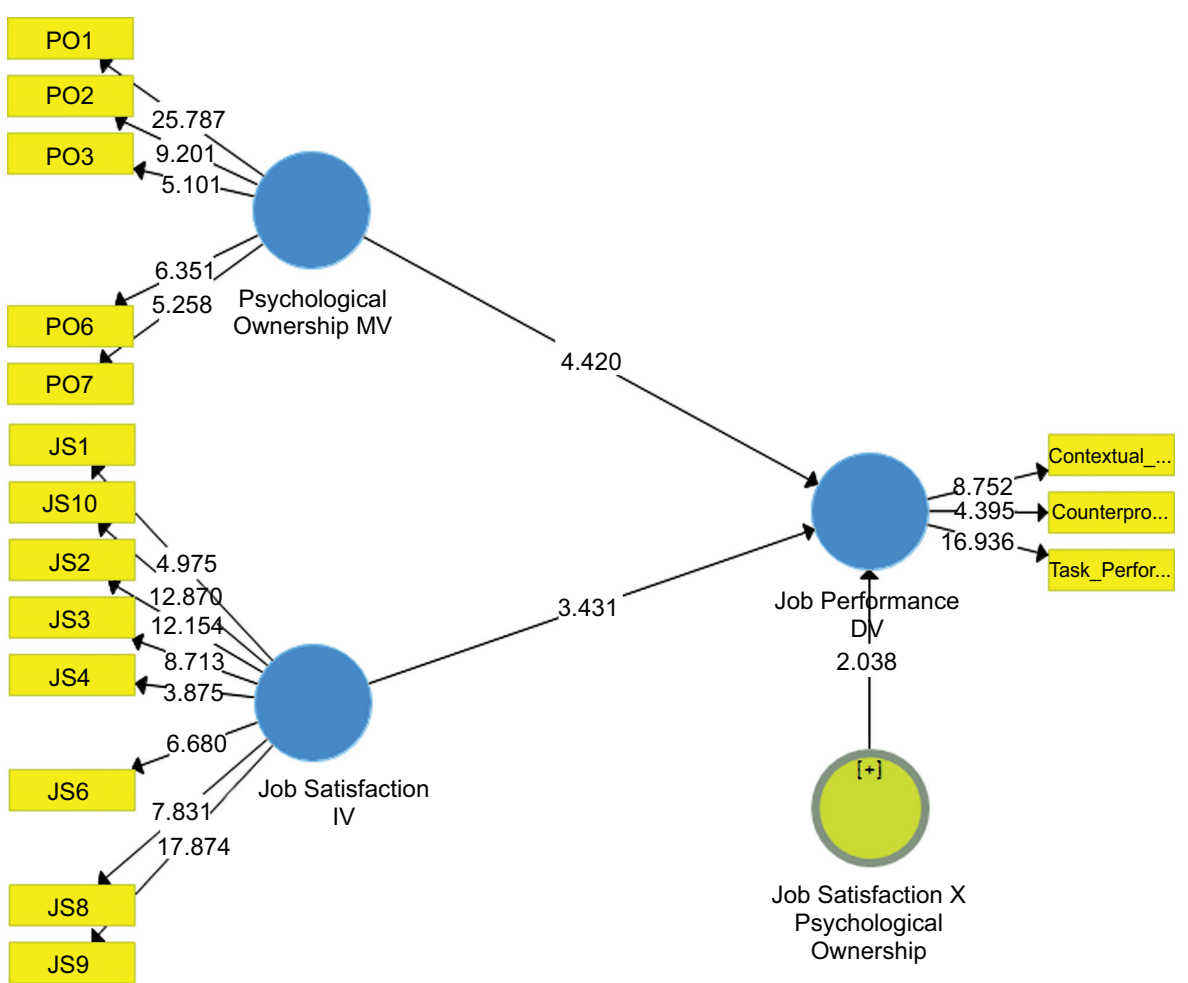

Psychological ownership

Source(s): PLS-SEM

supported hypothesis two. Similarly, the standardized path coefficient (Table 5) for the interaction effect is $F^{2}$ is $0.173 ; R^{2}$ is 0.558 at $p<0.05$. These results revealed that $\mathrm{PO}$ as a moderator has a significant positive interaction effect on the relationship between JS and JP.

\section{Discussion, theoretical and managerial implications}

\section{Discussion}

This study purposely examined the interaction effect of PO as a moderator on the relation between JS and JP among academic and non-academic employees. The study found that there is a positive significant interaction effect of $\mathrm{PO}$ on the relationship between JS and JP (Table 4). Furthermore, it is clear from the slope analysis (Figure 3) that PO changes the nature of relationship between JS and JP. The effect of JS on JP is weaker when PO is low and stronger when $\mathrm{PO}$ is higher. The interaction influences variation in JP by over $55 \%\left(R^{2} 0.558\right)$ compared with the direct effect with $R^{2}$ of $0.322(32 \%)$. This result meant that the interaction

\begin{tabular}{lccccccc}
\hline Hypotheses & Beta & $R^{2}$ & $t$-value & $F^{2}$ & Standard deviation & $Q^{2}$ & Decision \\
\hline H1 $\quad$ JS IV -> JP & 0.567 & 0.322 & $5.404^{* * * *}$ & 0.283 & 0.073 & 0.199 & Supported
\end{tabular}

Note(s): $t$-values $* * *=p<0.001$

Source(s): PLS-SEM

Table 4. Test of hypothesis (path coefficient) 
RAMJ

16,3 effect is larger based on the threshold of 0.35 for large interaction effect suggested by Cohen (1988). Therefore, high sense of PO among the employees strengthens their JS toward higher JP. In other words, their feeling of PO fosters their satisfaction with the job. The finding of this study is in line with the findings of previous studies (Valaei and Jiroudi, 2016; Yang and Hwang, 2014; Ferris et al., 2009; Foote and Li-Ping Tang, 2008).

\section{2}

\section{Table 5.}

Moderation effect

\begin{tabular}{lccccccc}
\hline Hypotheses & Beta & $R^{2}$ & $t$-value & $F^{2}$ & Standard deviation & $Q^{2}$ & Decision \\
\hline H2 JS X PO -> JP & 0.219 & 0.558 & $2.083^{* * *}$ & 0.173 & 0.075 & 0.213 & Supported
\end{tabular}

Note(s): $t$-values $*=p<0.05$

Figure 3.

Path coefficients (H1)

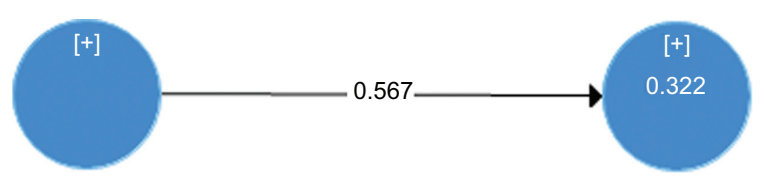

\section{Source(s): PLS-SEM}

Job performance

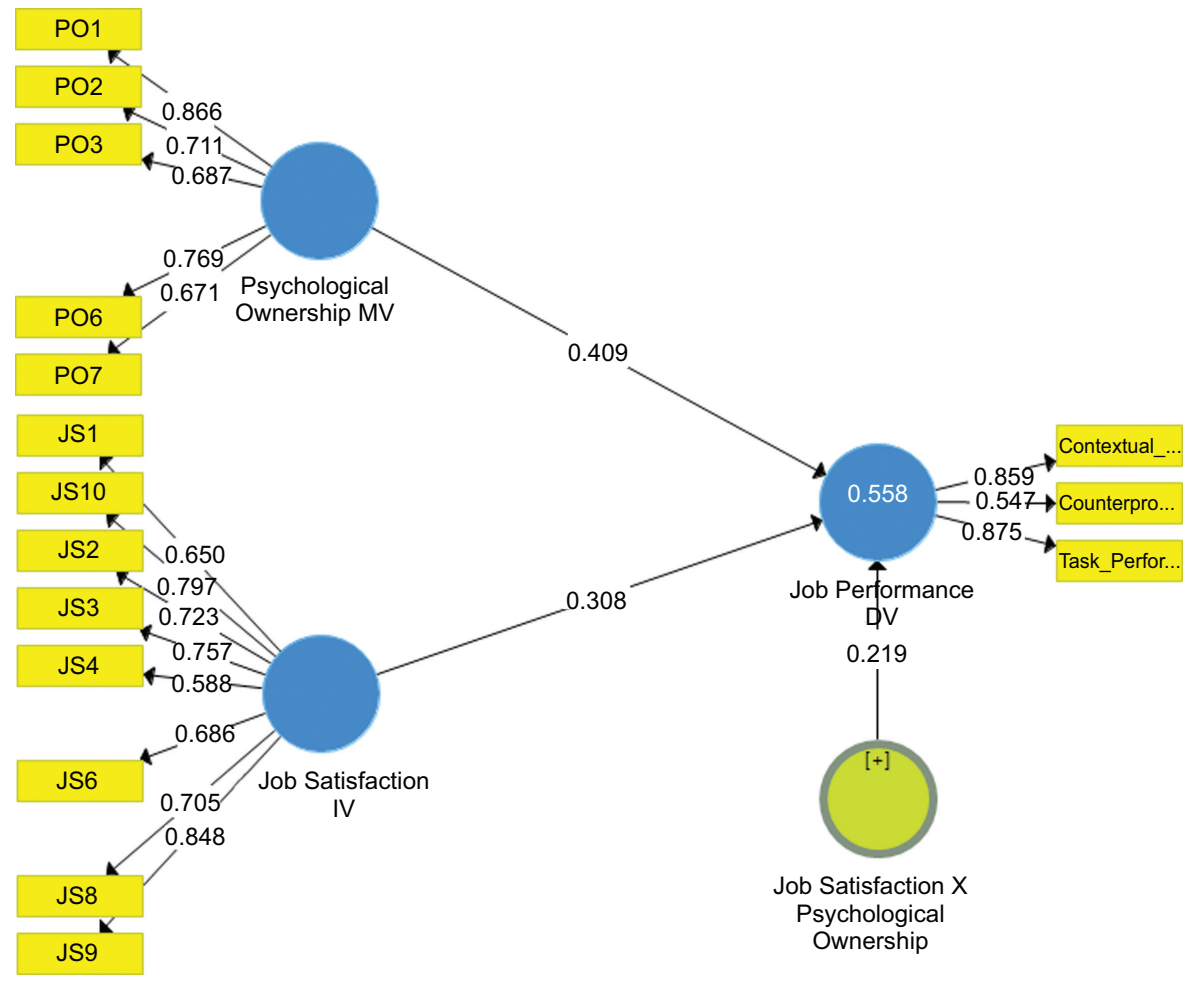

Source(s): PLS-SEM 


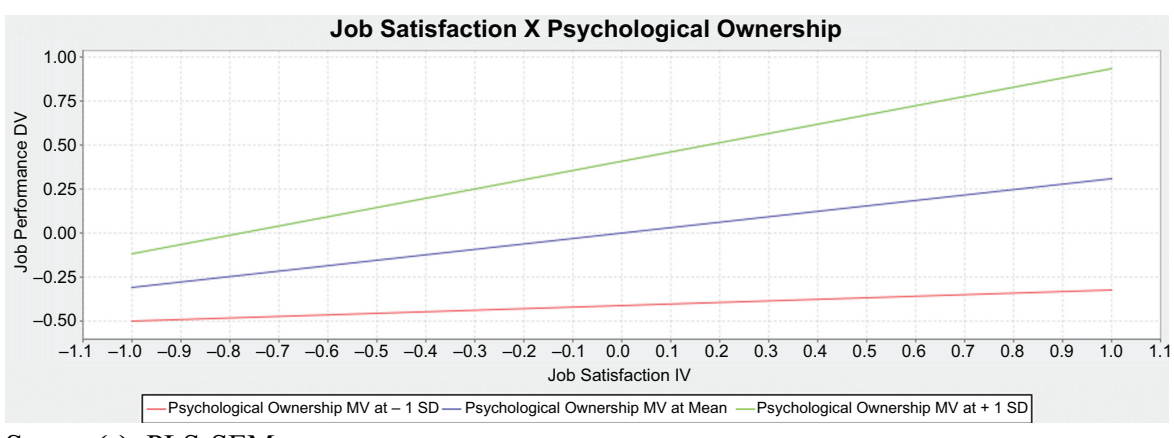

Psychological ownership

Source(s): PLS-SEM

203

\section{Theoretical implication}

The study has several valuable contributions to knowledge. First, previous studies have examined the relation between JS and JP across models suggested by Judge $e$ al. (2001) from different theoretical perspectives such as social psychological perspective (Zhang and Zheng, 2009), agency theory (Christen et al, 2006), affect-cognitive consistency perspective (Visser and Coetzee, 2005; Schleicher et al., 2004). This present study provides new insight into the relationship by drawing on the tripartite theory of attitude perspective, and concluded that JP as overall employee attitude toward the organization is predicted by the interaction and interplay of the affective component (JS), cognitive component (PO) and behavioral component (JP) of attitude. To our best knowledge, none of the previous literatures on JS-JP relationship draws its conclusions from the perspective of tripartite theory of attitude.

Second, the study contributed to the theory of PO. The present study found support that PO nurtures JS. The working condition of university employees in Nigeria is dissatisfying which portent the propensity of employee counterproductive/work deviance behaviors such as lateness, absenteeism and turnover (Judge and Kammeyer-Mueller, 2012). Lecturers in Nigerian universities owed over four month salaries (Chioma, 2020). Conversely, the study found that JS explained their performance by more than $32 \%$ and the interaction effect of PO accounted for more than $55 \%$ of their performance. Pierce et al. (2001) argued that PO comprises both cognitive and affective elements of attitude. These findings meant that their feeling of PO has fostered their JS. Third, the study addresses a cross-cultural gap suggested by Valaei and Jiroudi (2016). The study was carried out on new cultural context which adds to the generalizability of tripartite theory of attitude. To my best knowledge, this study is the first to empirically test the interaction effect of PO on the relationship between JS and JP.

Lastly, this study provides methodological contribution to the body of knowledge. Richter et al. (2016) noted that only $45(12 \%)$ out of 379 studies published in top International Business and Marketing journals utilized PLS-SEM rather than CB-SEM (co-variance based structural equation modeling). Similarly, Ali et al. (2018) reported that only 29 studies in six top hospitality journals utilized PLS-SEM between 2001 and 2015 and only three were on moderation effect. PLS-SEM is a more predictive-oriented approach and causal explanatory compared with CM-SEM; thus, it overcomes many of the well-known limitations of the CBSEM (Ringle et al., 2018). It is remiss of social science researchers if they did not apply all statistical methods at their disposal to explore and better understand the phenomena they are researching (Hair et al, 2019). Hence, this study contributed to the arguments that PLS-SEM approach should be utilized more. To our best knowledge, there is no existing literature that utilizes PLS-SEM to report an interaction effect on JS-JP relationship. This study contributed to this methodological gap. 
RAMJ

16,3

\section{Managerial implication}

The literature has documented that JS leads to positive employee behavioral outcomes which in turn leads to organizational performance, efficiency and effectiveness. However, there is a persistent literature controversy as to whether JS leads to JP. It is crucially important to explicate to human resource managers and practitioners the mechanism through which JS influences JP so that human resource practices in the organizations can be designed in such a way that ensures configuration of the mechanism in the organizational operations. The study found that the interaction of JS and PO explains variation in employee overall JP by over $55 \%$. The managerial implication of this finding is that organizations, human resource managers and practitioners can utilize PO as a strategy to strengthen employee JS toward higher JP.

Employee dissatisfaction causes high turnover, low commitment and absenteeism, and lateness (Farrell, 1983). A survey by INC. found that employees' turnover costs US companies $\$ 450-\$ 500$ bn annually (Albanee, 2018). The findings of this study concluded that feeling of PO by employees' fosters their satisfaction with the job. Employees who feel high sense of PO drive their satisfaction from that which in turn attenuates their feelings of dissatisfaction from the absence of JS factors in their workplaces toward higher performance. Therefore, when organizations strengthen organizational practices that encourage the feeling of PO among their employees they also strengthen their JS with the job. JS is fostered in employees' feelings of $\mathrm{PO}$ and strengthening their feelings of $\mathrm{PO}$ enhances their satisfaction with the job which in turn positively influences their overall JP.

\section{Conclusion and direction for future studies Conclusion}

The motivation of this study is to shed more light on the inconsistent conclusions on the relationship between JS and JP. The study draws its conclusions from the tripartite attitude theory and PO theory. The study purposely examined whether interaction effect of PO (cognitive component) changes the nature of the relationship between JS (affective component) and JP (behavioral component) toward higher or weaker effect. In addition, the study aims to find support whether PO nurtures JS. The study found a positive interaction effect of PO on the relationship between JS and JP such that higher feeling of PO means stronger effect of JS on JP. The study further concluded that feeling of PO nurtures employees' JS. The finding clarifies to human resource managers and practitioners the mechanism that enhances stronger effect of JS on JP.

\section{Direction for future research}

Very handful studies in the literature examined the moderating effect on the relationship between JS and JP. Future studies can explore the potential moderating effect of servant leadership particularly from the theoretical perspective of situational strength theory. Further studies can replicate this study on a different industry and culture. A mixed methodological study can also be explored to examine the model of this study. This will enhance the generalizability of the model particularly its theoretical base of tripartite theory of attitude.

\section{References}

Agustiningsih, H.N., Thoyib, A., Djumilah, H. and Noermijati, N. (2016), "The effect of remuneration JS and OCB on the employee performance", Science Journal of Business and Management, Vol. 4 No. 6, pp. 212-222.

Albanee, J. (2018), "Why employee satisfaction is at an all-time low-and what you can do about it", available at: https://wwwinccom/jason-albanese/why-employee-satisfaction-is-at-an-all-timelow-what-you-can-do-about-ithtml. 
Ali, F., Rasoolimanesh, S.M., Sarstedt, M., Ringle, C.M. and Ryu, K. (2018), "An assessment of the use of partial least squares structural equation modeling (PLS-SEM) in hospitality research", International Journal of Contemporary Hospitality Management, Vol. 30 No. 1, pp. 514-538.

Andersson, Ulf, Cuervo-Cazurra, A. and Nielsen, B.B. (2014), "From the editors: explaining interaction effects within and across levels of analysis", Journal of International Business Studies, Vol. 45, pp. 1063-1071.

Armstrong, M. and Taylor, S. (2014), Armstrong's Hand Book of Human Resource Management Practice, Kogan Page, London.

Avey, J.B., Avolio, B.J., Crossley, C.R. and Luthans, F. (2009), "PO: theoretical extensions measurement and relation to work outcomes", Journal of Organizational Behavior, Vol. 30, pp. 173-91.

Bailey, A.A., Albassami, F. and Al-Meshal, S. (2016), "The roles of employee JS and organizational commitment in the internal marketing-employee bank identification relationship", International Journal of Bank Marketing, Vol. 34 No. 6, pp. 821-840.

Bakotić, D. (2016), "Relationship between JS and organizational performance", Economic ResearchEkonomska Istraživanja, Vol. 29 No. 1, pp. 118-130.

Borman, W.C. and Motowidlo, S.J. (1997), "Task performance and contextual performance: the meaning for personnel selection research”, Human Performance, Vol. 10 No. 2, pp. 99-109.

Brief, A.P. and Weiss, H.M. (2002), "Organizational behavior: affect in the workplace", Annual Review of Psychology, Vol. 53, pp. 279-307.

Campbell, C.H., Ford, P., Rumsey, M.G., Pulakos, E.D., Borman, W.C., Felker, D.B., De vera, M.V. and Riegelhaupt, B.J. (1990), "Development of multiple job performance measures in a representative sample of jobs", Personnel Psychology, Vol. 43, pp. 277-300.

Chioma, U. (2020), "Some lecturers not paid for six month-ASUU", available at: https:// thenigerialawyer.com/some-lecturers-not-paid-for-six-months-asuu/.

Christen, M., Lyer, G. and Soberman, D. (2006), "JS JP and effort: a reexamination using agency theory", Journal of Marketing, Vol. 70, pp. 137-150.

Cohen, J. (1988), "Set correlation and contingency tables", Applied Psychological Measurement, Vol. 12 No. 4, pp. 425-434.

Culibrk, J., Delic, M., Mitrovic, S. and Culibrk, D. (2018), "JS organizational commitment and job involvement: the mediating role of job involvement", Frontiers in Psychology, Vol. 9, pp. 1-12.

Cummings, T. and Worley, C. (2014), Organization Development and Change, South-Western Cengage, Ohio.

Dåderman, A.M., Ingelgård, A. and Koopmans, L. (2019), "Cross-cultural adaptation, from dutch to Swedish language, of the individual work performance questionnaire”, Work, pp. 1-13, doi: 10. 3233/wor-193062.

Dawkins, S., Tian, A.W., Newman, A. and Martin, A. (2015), "PO: a review and research agenda", Journal of Organizational Behavior, Vol. 38 No. 2, pp. 163-183.

Eliyana, A., Sawitri, D. and Bramantyo, H. (2018), "Is JP affected by job motivation and JS?", The 2018 International Conference of Organizational Innovation (KnE Social Sciences), pp. 911-920.

Ezeamama, I.G. (2019), "JS and employee productivity in Anambra state Nigeria”, European Journal of Research in Social Sciences, Vol. 7 No. 2, pp. 1-13.

Fabrigar, L.R., MacDonald, T.K. and Wegener, D.T. (2005), "The structure of attitudes", in The Handbook of Attitudes, Routledge, doi: 10.4324/9781410612823ch3.

Farrell, D. (1983), "Exit voice loyalty and neglect as responses to job dissatisfaction: a multidimensional scaling study", Academy of Management Journal, Vol. 26 No. 4, pp. 596-607.

Ferris, G.R., Rogers, L.M., Blass, F.R. and Hochwarter, W.A. (2009), "Interaction of job-limiting pain and political skill on JS and organizational citizenship behavior", Journal of Managerial Psychology, Vol. 24 No. 7, pp. 584-608. 
RAMJ 16,3

Fontannaz, S. and Oosthuizen, H. (2007), "The development of a conceptual framework to guide sustainable job performance", South African Journal of Business Management, Vol. 38 No. 4, pp. 9-19.

Foote, D.A. and Li-Ping Tang, T. (2008), "JS and organizational citizenship behavior (OCB)", Management Decision, Vol. 46 No. 6, pp. 933-947.

Fuller, C.M., Simmering, M.J., Atinc, G., Atinc, Y. and Babin, B.J. (2016), "Common methods variance detection in business research”, Journal of Business Research, Vol. 69 No. 8, pp. 3192-3198.

Garg, K., Dar, I.A. and Mishra, M. (2017), "JS and work engagement: a study using private sector bank managers", Advances in Developing Human Resources, Vol. 20 No. 1, pp. 58-71.

Gaskin, J. (2017), "Common method bias (CMB) in PLS (partial least Square)", available at: https:// wwwyoutubecom/watch?v=J7eeu4O80_M.

Haddock, G., Zanna, M.P. and Esses, V.M. (1994), "The (limited) role of trait-laden stereotypes in predicting attitudes toward native peoples", British Journal of Social Psychology, Vol. 33 No. 1, pp. 83-106.

Hair, J.F., Risher, J.J., Sarstedt, M. and Ringle, C.M. (2019), "When to use and how to report the results of PLS-SEM", European Business Review, Vol. 31 No. 1, pp. 2-24.

Harrison, D.A., Newman, D.A. and Roth, P.L. (2006), "How important are job attitudes? Meta-analytic comparisons of integrative behavioral outcomes and time sequences", Academy of Management Journal, Vol. 49 No. 2, pp. 305-325.

Hazriyanto, I.B. and Silitonga, F. (2019), "Organizational commitment satisfaction and performance of lecturer (model regression by gender of man)", International Review of Management and Marketing, Vol. 9 No. 2, pp. 40-44.

Henseler, J. and Fassott, G. (2010), "Testing moderating EffectsPLS path models: an illustration of available procedures", in Esposito Vinzi, V., Chin, W. and Henseler J Wang, H. (Eds), Handbook of Partial Least Squares: Concepts, Methods and Applications (Springer Handbooks of Springer Handbooks of Computational Statistics), Springer Heidelberg, Berlin, pp. 713-735.

Henseler, J., Ringle, C.M. and Sinkovics, R.R. (2009), "The use of partial least squares path modeling in international marketing", in Sinkovics, R.R. and Ghauri, P.N. (Eds), Advances in International Marketing, Emerald, Bingley, pp. 277-320.

Henseler, J., Ringle, C.M. and Sarstedt, M. (2015), "A new criterion for assessing discriminant validity in variance-based structural equation modeling", Journal of the Academy of Marketing Science, Vol. 43 No. 1, pp. 115-135.

Hernandez, M. (2012), "Toward an understanding of the psychology of Stewardship", Academy of Management Review, Vol. 37 No. 2, pp. 172-193.

Hochwarter, W.A., Zellars, K.L., Perrewe, P.L. and Harrison, A.W. (1999), "The interactive role of negative affectivity and job characteristics: are high-NA employees destined to be unhappy at work?”, Journal of Applied Social Psychology, Vol. 29, pp. 2203-2218.

Hooper, D., Coughlan, J. and Mullen, M. (2008), "Structural equation modelling: guidelines for determining model fit”, Electronic Journal of Business Research Methods, Vol. 6 No. 1, pp. 53-60.

Hrdzic, K. (2016), Spirituality and Young Adults Work Performance, Master Thesis, Rochester Institute of Technology, Croatia.

Hu, L.T. and Bentler, P.M. (1999), "Cutoff criteria for fit indexes in covariance structure analysis: conventional criteria versus new alternatives", Structural Equation Modeling, Vol. 6 No. 1, pp. 1-55.

Hulland, J. (1999), "Use of partial least squares (PLS) in strategic management research: a review of four recent studies", Strategic Management Journal, Vol. 20 No. 2, pp. 195-204.

Iaffaldano, M.T. and Muchinsky, P.M. (1985), "JS and JP: a meta-analysis", Psychological Bulletin, Vol. 97 No. 2, pp. 251-273.

Idiegbeya-Ose, J., Arebgesola, A., Owolabi, S.E. and Eyiolorunshe, T. (2019), "Relationship between motivation and JS of staff in private libraries Nigeria", Academy of Strategic Management Journal, 
Vol. 18 No. 1, available at: http://eprints.lmu.edu.ng/2275/1/d4c32904e0b4a2fa0fa 076611877dc2e66d4.pdf.

Jackson, L.A., Hodge, C.N., Gerard, D.A., Ingram, J.M., Ervin, K.S. and Sheppard, L.A. (1996), "Cognition affect and behavior in the prediction of group Attitudes", Personality and Social Psychology Bulletin, Vol. 22 No. 3, pp. 306-316.

Johnson, J.W. (2001), "The relative importance of task and contextual performance dimensions to supervisor judgments of overall performance", Journal of Applied Psychology, Vol. 86 No. 5, pp. 984-996.

Judge, T.A. and Kammeyer-Mueller, J.D. (2012), "Job attitudes", Annual Review of Psychology, Vol. 63 No. 1, pp. 341-367.

Judge, T.A., Thoresen, C.J., Bono, J.E. and Patton, G.K. (2001), "The JS-JP relationship: a qualitative and quantitative review", Psychological Bulletin, Vol. 127 No. 3, pp. 376-407.

Kalleberg, A.L. (1977), "Work values and job rewards-theory of JS", American Sociological Review, Vol. 42, pp. 24-143.

Katz, D. and Stotland, E. (1959), "A preliminary statement to a theory of attitude structure and change", in Koch, S. (Ed.), Psychology: A Study of a Science, McGraw- Hill, New York.

Kline, R.B. (2011), Principles and Practice of Structural Equation Modeling, Guilford Press, New York.

Kock, N. (2015), "Common method bias in PLS-SEM: a full collinearity assessment approach", International Journal of E-Collaboration, Vol. 11 No. 4, pp. 1-10.

Koopmans, L., Bernaards, C.M., Hildebrandt, V.H., van Buuren, S., Allard, J., Beek, V.D. and de Vet, H.C.W. (2013), "Development of an individual work performance questionnaire", International Journal of Productivity and Performance Management, Vol. 62 No. 1, pp. 6-28.

Koopmans, L., Bernaards, C.M., Hildebrandt, V.H., de Vet, H.C.W. and van der Beek, A.J. (2014), "Construct validity of the individual work performance questionnaire", Journal of Occupational and Environmental Medicine, Vol. 56 No. 3, pp. 154-171.

Kozlowski, S.W.J. and Klein, K.J. (2000), "A multilevel approach to theory and research in organizations: contextual temporal and emergent processes", in Klein, K.J. and Kozlowski, S.W.J. (Eds), Multilevel Theory Research and Methods in Organizations: Foundations Extensions and New Directions, Jossey-Bass, San Francisco, pp. 3-90.

Li, J., Yuan, L., Ning, L. and Li-Ying, J. (2015), "Knowledge sharing and affective commitment: the mediating role of PO", Journal of Knowledge Management, Vol. 19 No. 6, pp. 1146-1166.

Liu, J., Wang, H., Hui, C. and Lee, C. (2012), "PO: how having control matters", Journal of Management Studies, Vol. 49 No. 5, pp. 869-895.

Locke, E.A. (1970), "JS and JP: a theoretical analysis", Organizational Behavior and Human Performance, Vol. 5 No. 5, pp. 484-500.

Lu, L., Liu, J. and Zhao, N. (2017), "Why employees stay: the roles of PO territoriality and work relationship closeness in affecting employee turnover intention", Frontiers of Business Research in China, Vol. 11 No. 10, doi: 10.1186/s11782-017-0010-x.

Macdonald, S. and MacIntyre, P. (1997), "The generic JS scale: scale development and its correlates", Employee Assistance Quarterly, Vol. 13 No. 2, pp. 1-16.

MacKenzie, S.B., Podsakoff, P.M. and Ahearne, M. (1998), "Some possible antecedents and consequences of in-role and extra-role salesperson performance", Journal of Marketing, Vol. 62, pp. 87-98.

Marcinkus, W.C., Whelan-Berry, K.S. and Gordon, J.R. (2007), "The relationship of social support to the work- family balance and work outcomes of midlife women", Women in Management Review, Vol. 22 No. 2, pp. 86-111.

Markovits, Y., Boer, D. and van Dick, R. (2014), "Economic crisis and the employee: the effects of economic crisis on employee JS commitment and self- regulation”, European Management Journal, Vol. 32 No. 3, pp. 413-422.

Psychological ownership 
RAMJ

16,3

Matzler, K. and Renzl, B. (2006), "The relationship between interpersonal trust employee satisfaction and employee loyalty", Total Quality Management, Vol. 17 No. 10, pp. 1261-1271.

Md-Sidin, S., Sambasivan, M. and Ismail, I. (2010), "Relationship between work-family conflict and quality of life: an investigation into the role of social support", Journal of Managerial Psychology, Vol. 259 No. 1, pp. 58-81.

Memon, M.A., Cheah, J.H., Ramayah, T., Ting, H., Chuah, F. and Cham, T.H. (2019), "Moderation analysis: issues and guidelines", Journal of Applied Structural Equation Modeling, Vol. 3 No. 1, pp. i-xi.

Millar, M.G. and Tesser, A. (1989), "The effects of affective-cognitive consistency and thought on the attitude-behavior relation”, Journal of Experimental Social Psychology, Vol. 25 No. 2, pp. 189-202.

Mira, M., Choong, Y. and Thim, C. (2019), “The effect of HRM practices and employees' JS on employee performance", Management Science Letters, Vol. 9 No. 6, pp. 771-786.

Mohamad, M.S. (2012), “Transformational leadership and employees' JS and commitment: a structural equation investigation", Journal of American Science, Vol. 8 No. 7, pp. 11-19.

Moorman, R.H. (1993), "The influence of cognitive and effective based JS measures on the relationship between satisfaction and organizational citizenship behavior", Human Relations, Vol. 6, pp. 759-776.

Mustafa, M., Martin, L. and Hughes, M. (2016), "Psychological ownership, job satisfaction, and middle manager entrepreneurial behavior", Journal of Leadership and Organizational Studies, Vol. 23 No. 3, pp. 272-287.

Nielsen, C. and Montemari, M. (2012), "The role of human resources in business model performance: the case of network-based companies", Journal of Human Resource Costing and Accounting, Vol. 16 No. 2, pp. 142-164.

Norris, D.R. and Niebuhr, R.E. (1984), "Organization tenure as a moderator of the JS-JP relationship", Journal of Vocational Behavior, Vol. 24 No. 2, pp. 169-178.

Ölçer, F. (2015), "Mediating effect of JS in the relationship between psychological empowerment and JP", Theoretical and Applied Economics, Vol. XXII No. 3, pp. 111-136.

Olofinkua, V.K. (2020), Academic Staff's JS and Motivation in Catholic Universities in Nigeria, M.Sc. Dissertations, Fordham University, New York.

Opeke, R., Ikonne, C.N. and Adewoyin, O.O. (2019), "JS among library personnel in public Universities in South-West Nigeria”, Journal of Information Knowledge Sharing, Vol. 10 No. 2, pp. 124-138.

Organ, D.W. (1988), Organizational Citizenship Behavior: The Good Soldier Syndrome, Lexington Books, Lexington MA.

Pierce, J.L., Kostova, T. and Dirks, K.T. (2001), "Toward a theory of PO in organizations”, Academy of Management Review, Vol. 26, pp. 298-310.

Podsakoff, P.M., MacKenzie, S.B., Lee, J.-Y. and Podsakoff, N.P. (2003), "Common method biases in behavioral research: a critical review of the literature and recommended remedies", Journal of Applied Psychology, Vol. 88 No. 5, pp. 879-903.

Richter, N.F., Sinkovics, R.R., Ringle, C.M. and Schlägel, C. (2016), “A critical look at the use of SEM in international business research”, International Marketing Review, Vol. 33 No. 3, pp. 376-404.

Ringle, C.M., Sarstedt, M., Mitchell, R. and Gudergan, S.P. (2018), "Partial least squares structural equation modeling in HRM research", The International Journal of Human Resource Management, Vol. 31 No. 12, pp. 1617-1643.

Robbins, S.P. and Judge, T.A. (2013), Organisational Behaviour, Pearson Education, New Jersey.

Robinson, S.L. and Bennett, R.J. (1995), "A typology of deviant workplace behaviors: a multidimensional scaling study", Academy of Management Journal, Vol. 38, pp. 555-572.

Rosenberg, M.J. and Hovland, C.I. (1960), "Cognitive affective and behavioral components of attitudes", in Rosenberg, M.J. (Ed.), Attitude Organization and Change: An Analysis of Consistency Among Attitude Components, Yale University Press, New Haven, Connecticut, pp. 1-14. 
Sarstedt, M., Ringle, C.M. and Hair,J.F. (2017), "Partial least squares structural equation modeling", in Homburg, C., Klarmann, M. and Vomberg, A. (Eds), Handbook of Market Research, Springer, Heidelberg.

Schleicher, D.J., Watt, J.D. and Greguras, G.J. (2004), "Reexamining the JS- performance relationship: the complexity of attitudes", Journal of Applied Psychology, Vol. 89 No. 1, pp. 165-177.

Schwab, D. and Cummings, L. (1970), "Theories of performance and satisfaction: a review", Industrial Relations, Vol. 9, pp. 408-430.

Scimago Institution Ranking (2020), available at: https://wwwscimagoircom/rankingsphp? country $=$ NGA.

Shmueli, G. and Koppius, O.R. (2011), "Predictive analytics in information systems research", MIS Quarterly, Vol. 35 No. 3, pp. 553-572.

Spector, P.E. (1997), Job Satisfaction: Application, Assessment, Causes and Consequences, Sage Publications.

Srivastava, S. (2013), "JS and organizational commitment relationship: effect of personality variables vision", The Journal of Business Perspective, Vol. 17 No. 2, pp. 159-167.

Susan, A. (2012), "Job satisfaction as an antecedent to employee engagement", SIES Journal of Management, Vol. 8 No. 2, pp. 27-36.

Tella, A. and Ibinaiye, O.A. (2019), "Correlates of staff motivation satisfaction and JP of library staff in selected Nigerian university libraries", International Information and Library Review, Vol. 52 No. 1, pp. 1-18.

Theresia, L., Lahuddin, A.H., Ranti, G. and Bangon, R. (2018), "The influence of culture JS and motivation on the performance of lecturers/employees", in (Paper Presented) Industrial Engineering and Operations Management Bandung Indonesia, March 6-8, available at: http:// ieomsocietyorg/ieom2018/papers/506pdf.

Thompson, E.R. and Phua, F.T.T. (2012), "A brief index of affective JS”, Group and Organization Management, Vol. 37 No. 3, pp. 275-307.

Tian, K. and Belk, R.W. (2005), "Extended self and possessions in the workplace", Journal of Consumer Research, Vol. 32 No. 2, pp. 297-310.

Valaei, N. and Jiroudi, S. (2016), "JS and JP in the media industry", Asia Pacific Journal of Marketing and Logistics, Vol. 28 No. 5, pp. 984-1014.

Van Dyne, L. and Pierce, J.L. (2004), "PO and feelings of possession: three field studies predicting employee. Attitudes and organizational citizenship behavior", Journal of Organizational Behavior, Vol. 25 No. 4, pp. 439-459.

Visser, D. and Coetzee, S. (2005), "Affective-cognitive consistency of attitude as a moderator of the JSperformance relationship", SA Journal of Industrial Psychology, Vol. 31 No. 3, pp. 62-69.

Westover, J.H. and Taylor, J. (2010), "International differences in JS: the effects of public service motivation rewards and work relations", International Journal of Productivity and Performance Management, Vol. 59 No. 8, pp. 811-828.

Williams, L.J. and Anderson, S.E. (1991), "JS and organizational commitment as predictors of organizational citizenship and in-role behaviors", Journal of Management, Vol. 17 No. 3, pp. 601-617.

Yang, C.L. and Hwang, M. (2014), "Personality traits and simultaneous reciprocal influences between JP and JS", Chinese Management Studies, Vol. 8 No. 1, pp. 6-26.

Zanna, M.P. and Rempel, J.K. (1988), "Attitudes: a new look at an old concept", in A W Kruglanski, D.B.T. (Ed.), The Social Psychology of Knowledge, Editions de la Maison des Sciences de l'Homme, Paris, pp. 315-334.

Zeffane, R., Ibrahim, M.E. and Al Mehairi, R. (2008), "Exploring the differential impact of JS on employee attendance and conduct: the case of a utility company in the United Arab Emirates", Employee Relations, Vol. 30 No. 3, pp. 237-250.
Psychological ownership 
RAMJ

16,3

Zhang, J. and Zheng, W. (2009), "How does satisfaction translate into performance? An examination of commitment and cultural values", Human Resource Development Quarterly, Vol. 20 No. 3, pp. 331-351.

Zhang, Y., Liu, G., Zhang, L., Xu, S. and Cheung, M.W.L. (2020), "Psychological ownership: a metaanalysis and comparison of multiple forms of attachment in the workplace", Journal of Management, Vol. 47 No. 3, pp. 745-770, doi: 10.1177/0149206320917195.

\section{0}

\section{Further reading}

Fornell, C. and Larcker, D.F. (1981), "Evaluating structural equation models with unobservable variables and measurement error", Journal of Marketing Research, Vol. 18 No. 1, pp. 39-50.

Lembani, R.L. (2019), “Country report on Nigerian university education-2019”, available at: http:// ideaspartnershiporg/userassets/IDEAS_Nigeria_Country_Report_2019_FINALpdf.

Locke, E.A. (1976), “The nature and causes of JS”, in Dunette, M.D. (Ed.), Handbook of Industrial and Organization Psychology, RanMc Nally, Chicago, pp. 1297-1343.

Luthans, F. (2011), Organizational Behavior: An Evidence-Based Approach, McGraw-Hill/Irwin, New York.

Nigerian University System Statistical Digest (2017), available at: https:/nucedung/wp-content/ uploads/2018/12/REVISED-April-25-Statistical-Digest-minpdf.

Pierce, J.L., Kostova, T. and Dirks, K.T. (2003), "The state of PO: integrating and extending a century of research", Review of General Psychology, Vol. 7, pp. 84-107.

Riketta, M. (2008), "The causal relation between job attitudes and performance: a meta- analysis of panel studies", Journal of Applied Psychology, Vol. 93 No. 2, pp. 472-481.

Vanguard Online (2016), "We need 100,000 new lecturers for Nigerian varsitie-ASUU", available at: https://wwwvanguardngrcom/2016/07/we-need-100000-new-lecturers-for-nigerian-varsities-asuu/. 


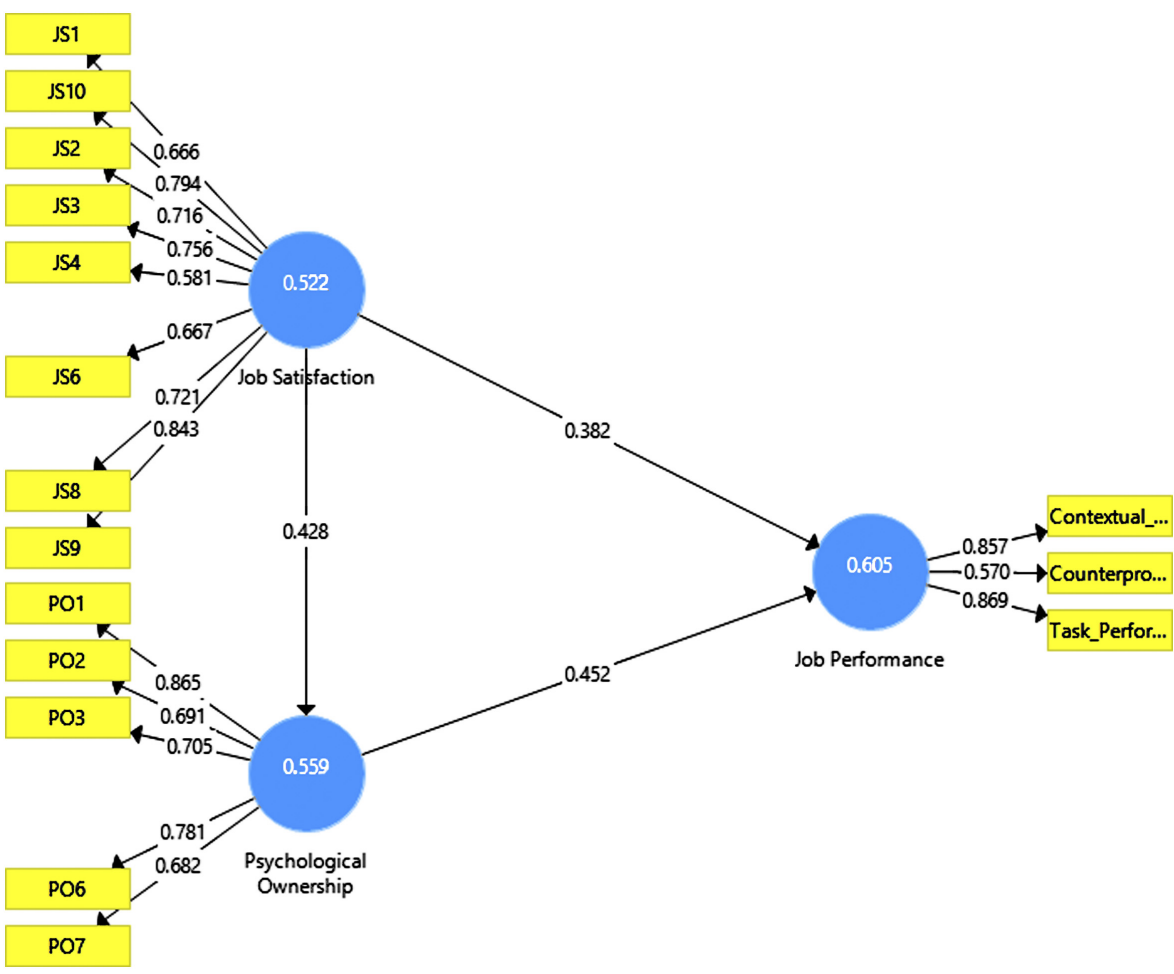

Figure A1.

Outer weights/factor loadings/average variance extracted

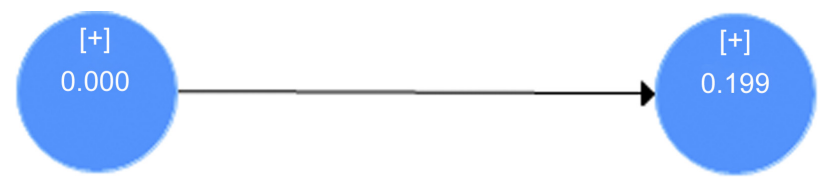

Job satisfaction

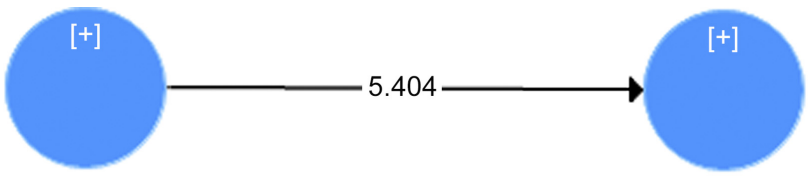

Job satisfaction
Job performance

Job performance
Figure A2.

JS-JP predictive relevance $\left(Q^{2}\right)$

Figure A3. JS-JP $t$-values 
RAMJ

16,3

\section{2}

Figure A4.

Interaction effect predictive

relevance $\left(Q^{2}\right)$

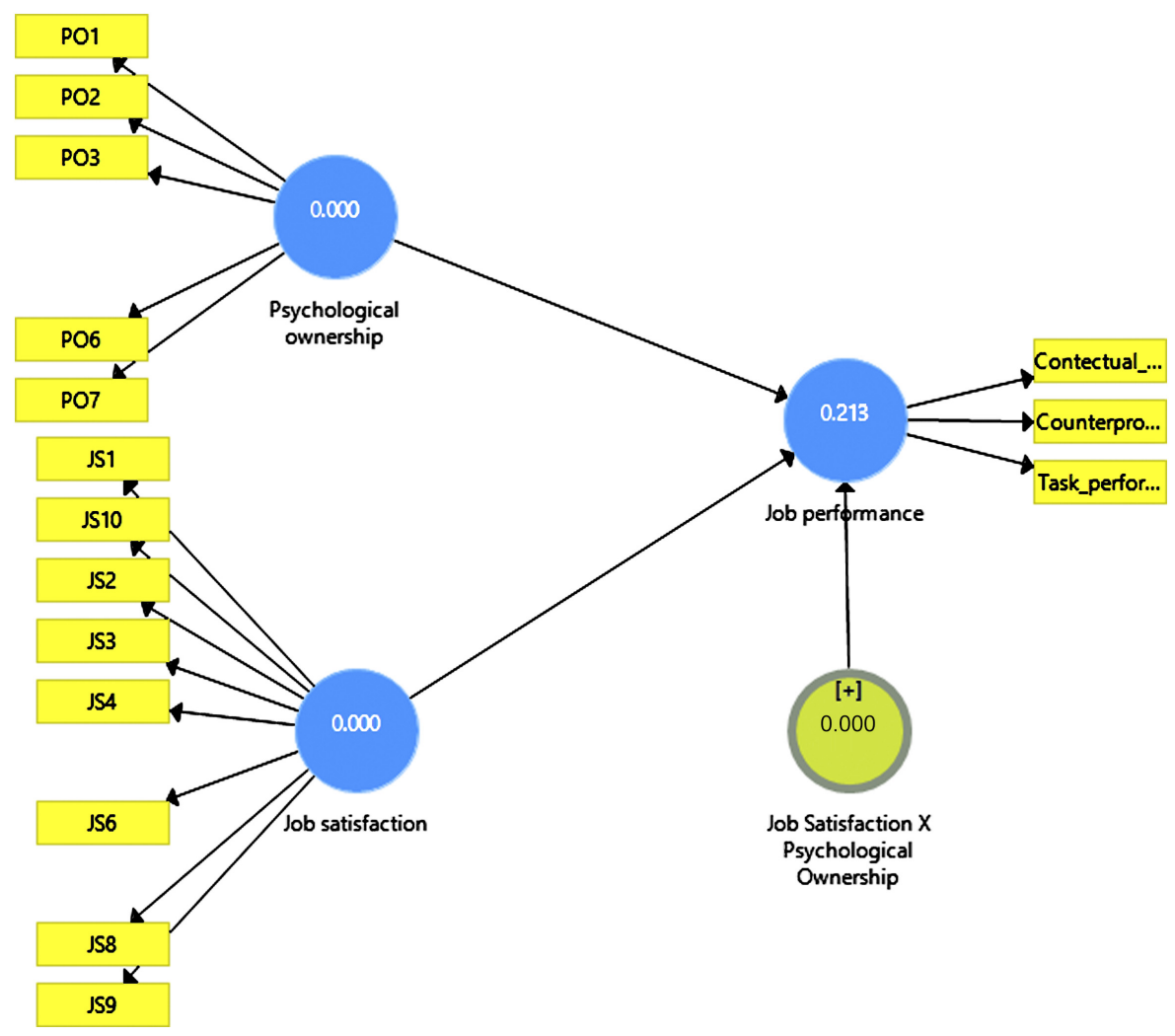

Corresponding author

Muhammad Bello Jakada can be contacted at: jakadamuhammadb@yahoo.com

For instructions on how to order reprints of this article, please visit our website:

www.emeraldgrouppublishing.com/licensing/reprints.htm

Or contact us for further details: permissions@emeraldinsight.com 